2000-07

Limaria hians (Mollusca: Limacea): a neglected reef-forming keystone species

\author{
Hall-Spencer, Jason
}

http://hdl.handle.net/10026.1/1363

10.1002/1099-0755(200007/08)10:4<267::aid-aqc407>3.0.co;2-b

Aquatic Conservation: Marine and Freshwater Ecosystems

Wiley

All content in PEARL is protected by copyright law. Author manuscripts are made available in accordance with publisher policies. Please cite only the published version using the details provided on the item record or document. In the absence of an open licence (e.g. Creative Commons), permissions for further reuse of content should be sought from the publisher or author. 


\title{
Limaria hians (Mollusca: Limacea): a neglected reef-forming keystone species
}

\author{
J.M. HALL-SPENCER ${ }^{\mathrm{a}, *}$ and P.G. MOORE ${ }^{\mathrm{b}}$

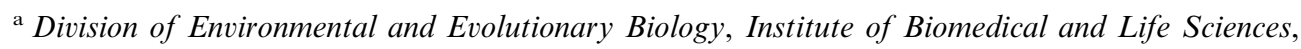 \\ University of Glasgow, UK \\ ${ }^{\mathrm{b}}$ University Marine Biological Station, Millport, Isle of Cumbrae, UK
}

\begin{abstract}
1. The case is made for recognition of the marine bivalve Limaria hians as a reef-forming species, which plays a key architectural role in certain benthic communities around the United Kingdom and Ireland.

2. This species uses byssal threads to construct nests that can coalesce to form reefs that cover hectares of seabed, contain multiple conspecifics and bind sediment. In so doing, L. hians modifies physical, chemical and biological processes at the sediment-water interface.

3. Such nests support a high diversity of associated organisms in coarse-grade sediments (19 species of algae and 265 species of invertebrates from six discrete nests in Loch Fyne are reported on), although the biological interactions between species both inside and outside this assemblage (e.g. predatory cod) are unknown.

4. Being insubstantial, labyrinthine structures situated on the sediment surface, Limaria nests are sensitive to mechanical impacts, such as those caused by moorings, hydraulic dredging for infaunal bivalves and scallop dredging.

5. At appropriate sites, the status of L. hians can contribute a useful indication of disturbance on coarse-grade sediments.

Copyright (C) 2000 John Wiley \& Sons, Ltd.
\end{abstract}

KEY WORDS: biodiversity; biogenic reef; keystone species; Limaria; scallop dredging

\section{INTRODUCTION}

It has long been recognized that beds of oysters and mussels play an important structural role in coastal waters, providing habitats for characteristic assemblages of organisms (Möbius, 1883; Erwin et al., 1990; Seed, 1996; Holt et al., 1998). Such organisms, along with other high profile (e.g. hermatypic corals) and lesser known reef-forming organisms (e.g. tubeworms) represent keystone species, which form complex structural habitats of high biodiversity (Bosence, 1973; Anadon, 1981; Minchin, 1987; Ray et al., 1997; Holt et al., 1998; Moore et al., 1998).

\footnotetext{
* Correspondence to: Division of Environmental and Evolutionary Biology, Institute of Biomedical and Life Sciences, Graham-Kerr Building, University of Glasgow, Glasgow, G12 8QQ, UK.

Copyright (C) 2000 John Wiley \& Sons, Ltd.

Received 3 November 1999 Accepted 6 February 2000
} 
The conservation significance of biogenic reefs resides both in their high biodiversity and their sensitivity to damage from anthropogenic impacts (Newell, 1988; Williams and Williams, 1990; Magorrian et al., 1995; MacDonald et al., 1996; Ray et al., 1997; Service and Magorrian, 1997; Holt et al., 1998; Lenihan and Peterson, 1998; Magorrian and Service, 1998; Moore et al., 1998; Cranfield et al., 1999). The last decade has seen moves to establish marine protection areas following agreements such as the Rio de Janeiro Convention on Biodiversity, the European Union's 'Habitats Directive' and the Oslo/Paris Convention OSPAR. In the UK, emphasis has been placed on the importance of biogenic reefs constructed by mussels (Modiolus modiolus and Mytilus edulis) and tubeworms (Sabellaria spinulosa and S. alveolata) within a proposed network of marine Special Areas of Conservation (SACs) (Holt et al., 1998).

Our work on the ecology of maerl beds in European waters (BIOMAERL Team, 1999; Hall-Spencer and Moore, 2000) has drawn our attention to another type of biogenic reef, which has so far received scant recognition in the literature: that associated with Limaria hians (Gmelin), "the most beautiful British bivalve' (Yonge and Thompson, 1976). Commonly known as the gaping file shell, this species has a thin delicately ribbed shell up to $4 \mathrm{~cm}$ in length with a gap running along the dorsal side of the animal, even when the valves are closed (hence 'gaping'). The red mantle tissue is fringed with long orange tentacles that cannot be withdrawn but extend out into the surrounding water (Figure 1).

Holt et al. (1998) recently defined biogenic reefs as 'solid, massive structures which are created by accumulations of organisms, usually arising from the seabed, or at least clearly forming a substantial, discrete community or habitat which is very different from the surrounding seabed. The structure of the reef may be composed almost entirely of the reef building organism and its tubes or shells, or it may to some degree be composed of sediments, stones and shells bound together by the organisms'. These authors dismissed L. hians beds from consideration as biogenic reefs and suggested that they were 'probably best regarded as semi-infaunal bivalve beds'. However, we have surveyed L. hians beds that meet all criteria of the above definition and with this contribution we seek to highlight the complexity of the Limaria association and to advance the argument for this neglected association being accorded a greater conservation priority than has been the case to date.

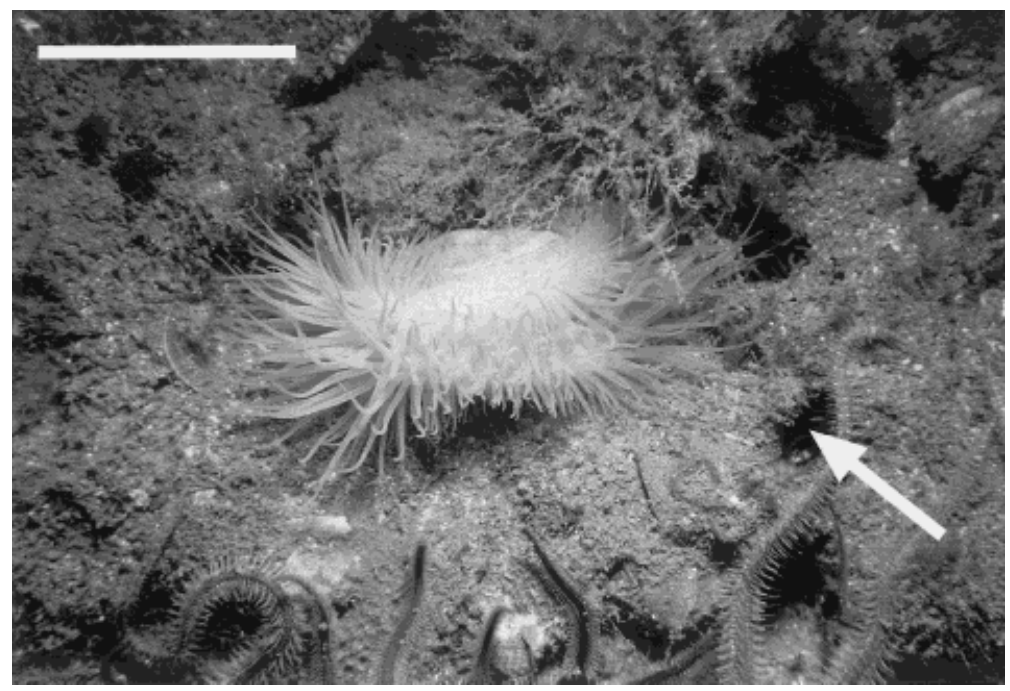

Figure 1. Adult L. hians seen on nest surface at $-10 \mathrm{~m}$ Creag Gobhainn, Loch Fyne, October 1999. Note the long pallial tentacles that cannot be withdrawn into the shell. Ventilation holes (arrow) lead to galleries that ramify through the nest. Scale bar $=3 \mathrm{~cm}$. 


\section{DISTRIBUTION OF LIMARIA HIANS}

Although records of $L$. hians are patchy, they extend from the Mediterranean south to the Canary Islands $\left(28^{\circ} \mathrm{N}\right)$ up to the Lofoten Islands $\left(68^{\circ} \mathrm{N}\right)$ in the northeast Atlantic (Tebble, 1966; Høistæter, 1986). This species has never been recorded in eastern parts of the English Channel or south of Orkney in the North Sea, but it does occur on west coasts of the British Isles, particularly Scotland (Tebble, 1966; Seaward, 1982). It has been found amongst kelp holdfasts and on a variety of coarse, shallow sublittoral grounds but not beyond a depth of $100 \mathrm{~m}$ (Tebble, 1966). Connor et al. (1997) recorded the L. hians facies as scarce in the UK and associated it with mixed muddy gravel and sand (see also Marine Biological Association, 1957) in weak to moderately strong tidal streams. In the Clyde Sea/Mull of Kintyre area, isolated areas with $L$. hians have been found on substrata ranging from coarse sands, gravels, muddy maerl and bedrock in places where there are weak to strong tidal streams $\left(0.25-1.5 \mathrm{~m} \mathrm{~s}^{-1}\right)$ at depths of 4-98 m (Allen, 1962; J.M. Hall-Spencer, personal observation). Discrete areas of L. hians have also been reported in the tidal narrows of Mulroy Bay (Republic of Ireland) (Praeger, 1894; Picton et al., 1994) and several Scottish sea lochs including Lochs Broom, Linnhe and Sunart (Howson et al., 1994). Although there are insufficient data to describe the current status of L. hians, it seems fairly certain that its distribution and numbers have declined dramatically over recent decades (see the discussion section).

\section{NEST-BUILDING BEHAVIOUR OF LIMARIA HIANS}

Several Limaria species form characteristic nests constructed with byssal threads (Jeffreys, 1863; MacGinitie and MacGinitie, 1968; Yonge and Thompson, 1976); a trait that is uncommon within the Bivalvia (Merrill and Turner, 1963). Jeffreys (1863) reported that L. hians built nests lined with excrement under large stones, mingling byssus threads with shell and nullipore (= maerl). Tebble (1966) described nests up to $25 \mathrm{~cm}$ across, with holes for the entrance and exit of water currents. Gilmour (1967) investigated the construction of L. hians nests in aquaria and found that individuals 'sewed together' several hundred byssal fibres to construct nests. The diameter of these nests was defined by the maximum gape of the shell valves of the animal, while the length of the nest was usually about twice that of the shell. These and other, old descriptions of L. hians nests are mostly based on dredged samples and fail to convey the scale of the constructions that we have observed in Loch Fyne, or that have been encountered on recent scuba surveys of other sea lochs on the west coast of Scotland (Howson et al., 1994). In the tidal narrows systems of sea lochs, L. hians nests can form continuous reefs standing 10-20 cm high covering several hectares in extent (J.M. Hall-Spencer, personal observation).

There has been some confusion in the literature over the single/multiple occupancy of L. hians nests. Jeffreys (1863) and Step (1927) reported that young L. hians associated in nests while the adults were solitary. Robertson (in Jeffreys, 1863) and Tebble (1966) emphasized that the nests were not incubation chambers but could be occupied by one adult or several young, while Gilmour (1967) never noted more than one animal per nest.

During a 5 year study involving regular diving surveys in the Creag Gobhainn area of Loch Fyne (BIOMAERL Team, 1999; Hall-Spencer and Moore, 2000), we found that several bordering biotopes graded gradually into a region where $L$. hians formed a continuous byssus reef with densities $>700$ individuals $\mathrm{m}^{-2}$ situated in $15 \mathrm{~m}$ depth at $56^{\circ} 00.601^{\prime} \mathrm{N} 005^{\circ} 22.148^{\prime} \mathrm{W}$ (determined by Magellan Global Positioning System). In a zone about $200 \mathrm{~m}$ from the continuous Limaria reef, gaping file shells were scarce $\left(<0.1 \mathrm{~m}^{-2}\right)$ and typically found singly in nests of $2-5 \mathrm{~cm}$ diameter. These small nests were attached to the sides of cobbles, embedded in maerl gravel or in the holdfasts of the kelp Laminaria saccharina. Nests were more common at about $100 \mathrm{~m}$ from the main Limaria reef (Hall-Spencer and Moore, 2000) and were similar to those described by Step (1927) and Tebble (1966). Each was ca $25 \mathrm{~cm}$ 
in diameter and $10 \mathrm{~cm}$ high with clumps of byssus that resembled matted hair with numerous holes over the nest surface leading to galleries below (Figure 1). When six nests of this size were collected in October 1999, each contained 24-52 small L. hians $(0.3-2.5 \mathrm{~cm}$ length) and 25-40 large individuals $(2.5-4.0 \mathrm{~cm}$ shell length). Multiple occupancy of nests by L. hians of mixed sizes was also described by Dennis (in Jeffreys, 1863). The large size of many of the specimens collected at Creag Gobhainn was interesting (44\% were $2.5-4.0 \mathrm{~cm}$ long) considering that Hayward and Ryland (1996) quoted the maximum shell length for L. hians as $2.5 \mathrm{~cm}$, while Tebble (1966) reported that the shells were rarely more than $1 \mathrm{in} .(2.54 \mathrm{~cm})$ long. Our preliminary observations support the view that adults occupy individual galleries within each nest, each gallery having two narrow openings at the exterior of the nest, while the juveniles share more complex galleries with multiple openings at the nest surface. On the main L. hians reef at Creag Gobhainn, discrete nests did not occur, instead a felty mat of byssus threads interwoven with shell, stones and maerl formed a continuous reef over several hectares of the seabed. The reef stood $10-20 \mathrm{~cm}$ high and was encrusted with a variety of attached organisms, which further consolidated the reef (see below).

Our observations of L. hians reefs in Loch Fyne involved over eighty 30-60-min dives from 1995 to 1999, and indicate that the reef structure provides protection from predation. On one occasion (October 1999) a commercial scallop fishing boat with six Newhaven dredges per side towed through part of the Limaria reef at Creag Gobhainn. Diving $3 \mathrm{~h}$ after dredging revealed that the reef had been ripped apart and mostly removed along the dredged path of a single pass of the gear. Damaged L. hians left on the dredge track had attracted a dense aggregation of scavengers. Repeat dives over the following 3 days revealed that the flesh from the file shells was consumed within $24 \mathrm{~h}$ by juvenile cod (Gadus morhua), dragonets (Callionymus sp.), dogfish (Scyliorhinus canicula), edible whelks (Buccinum undatum), brittlestars (Ophiocomina nigra), swimming crabs (Liocarcinus depurator) and hermit crabs (Pagurus bernhardus, Figure 3).

Step (1927) interpreted Limaria nests as providing protection against predation by cod, which, he wrote, 'have a weakness for Lima flesh'. That being the case (cf. Côté, 1995 and Reimer and Tedengren, 1997 on Mytilus), the feeding activities of shoals of juvenile cod noted on the surface of Limaria reefs (Figure 4) might naturally enhance byssal production and thereby strengthen nest defences. However, a few apparently healthy L. hians were occasionally seen outside their protective byssus nests (Figures 1 and 2),

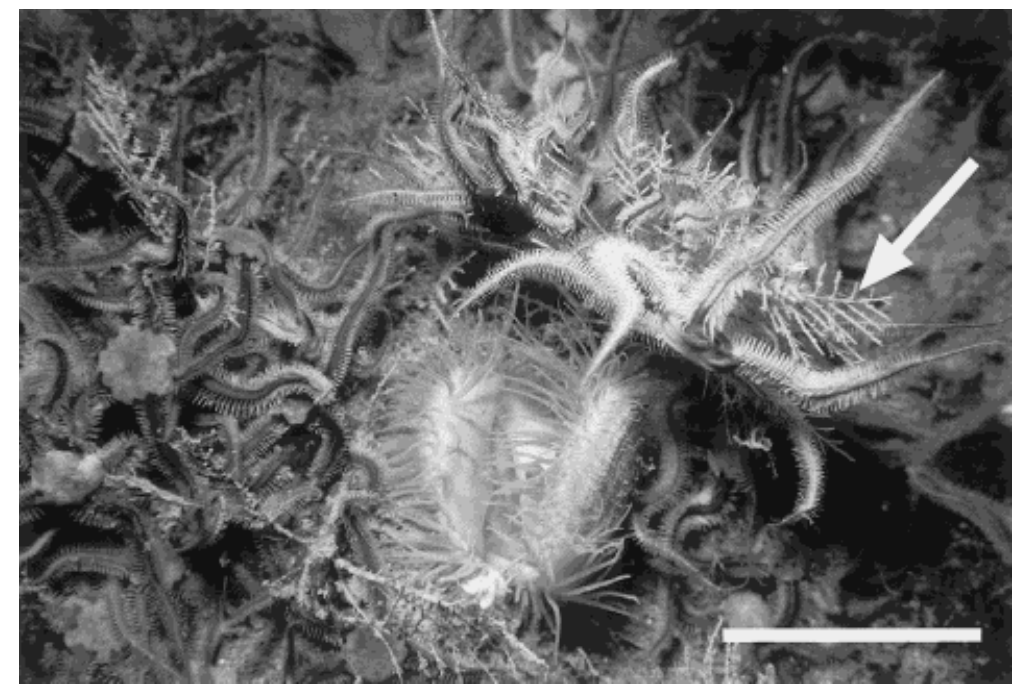

Figure 2. Adult L. hians (bottom centre) emergent from a nest at $-15 \mathrm{~m}$ Creag Gobhainn, Loch Fyne, October 1999 . The nest surface is covered in attached hydroids (arrow) and vagile brittlestars. Scale bar $=3 \mathrm{~cm}$. 
but were not attacked by predators. It seems likely that undamaged $L$. hians are less attractive to predators than damaged individuals since healthy $L$. hians may escape predation by swimming and, if captured, can autotomize pallial tentacles that secrete a viscous, acrid-smelling mucus, which sticks to predators such as fish and crabs (Gilmour, 1967).

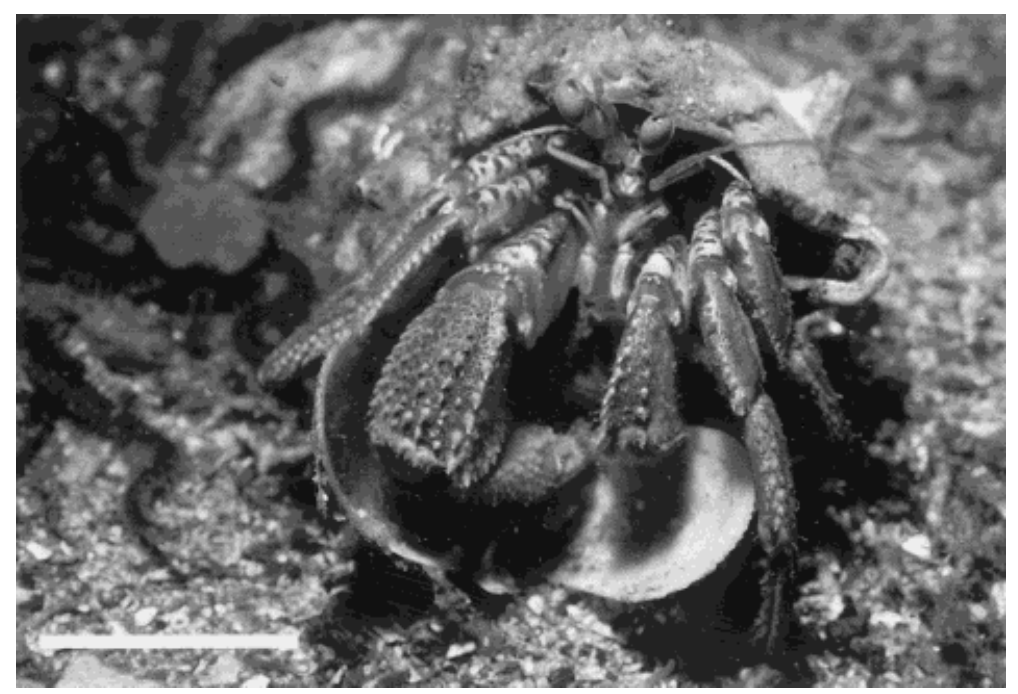

Figure 3. Pagurus bernhardus feeding on a L. hians exposed and damaged by the passage of Newhaven scallop dredges at $-18 \mathrm{~m}$ Creag Gobhainn, Loch Fyne, October 1999. Scale bar $=4 \mathrm{~cm}$.

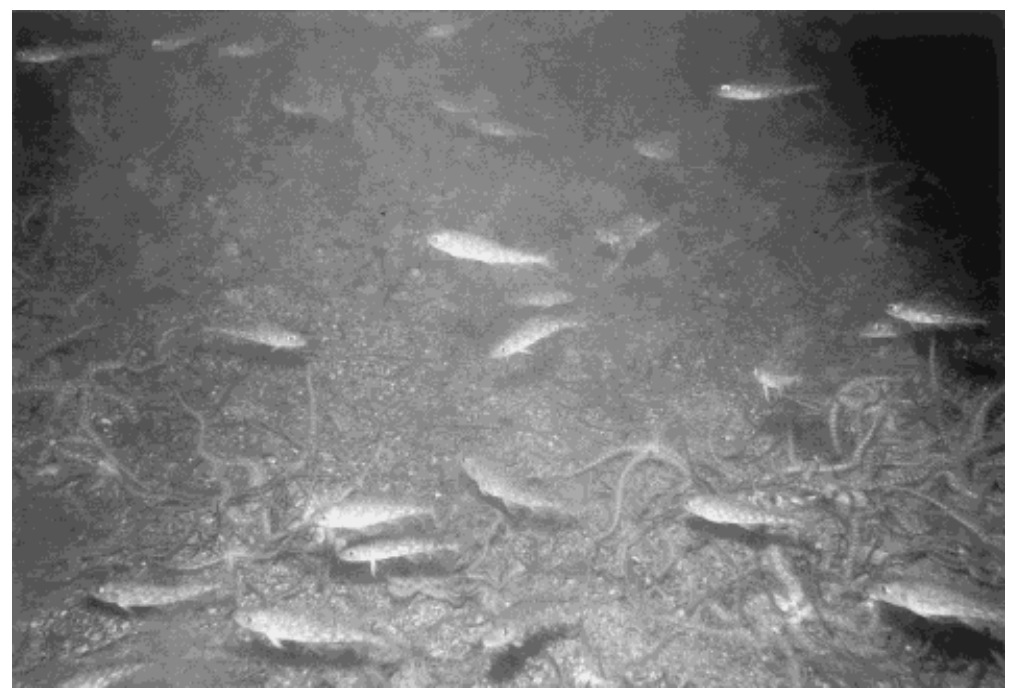

Figure 4. School of 8-10 cm long juvenile cod (Gadus morhua) feeding on the surface of a L. hians reef at $-15 \mathrm{~m}$ Creag Gobhainn, Loch Fyne, October 1999. 


\section{THE FLORA AND FAUNA ASSOCIATED WITH LIMARIA HIANS}

One of the most striking features of the L. hians nests studied was the array of organisms that associated with, and depended upon, the physical structure of the nests. Over the past 5 years, monitoring by divers and repeated sampling using a $0.1 \mathrm{~m}^{2}$ van Veen grab in Loch Fyne (Hall-Spencer and Moore, 2000) has revealed that L. hians nests are a stable feature on the seabed from $4 \mathrm{~m}$ to at least $28 \mathrm{~m}$ below Chart Datum in the Creag Gobhainn area. In situ observations, collections of nests while diving and remote grab sampling all showed that the nests had a diverse assemblage of organisms associated with them. Appendix A lists the macroflora and invertebrate macrofauna found on and in six discrete nests from the Creag Gobhainn area of Loch Fyne in 1998-1999 and provides an insight into the high levels of biodiversity that typified this habitat. The six chosen nests were of similar size and shape, being roughly circular as seen from above and ranging from 23 to $30 \mathrm{~cm}$ in diameter. A diver gently lifted each nest off the seabed by hand and quickly encased it in a strong plastic bag, which was tied closed and placed in a second plastic bag to retain the nest and its contents. The bagged samples were stored in seawater at $10^{\circ} \mathrm{C}$ overnight. The next day each nest was laid in a tray of clean seawater while the macrofauna and flora were removed with forceps. The nests were encrusted by an abundance of sessile organisms, such as macroalgae, hydroids and barnacles, which used the nests as a surface for attachment in an otherwise sedimentary habitat (Figure 2). Once surface dwelling organisms had been removed, the nests were teased apart to remove the burrowing inhabitants. Before discarding, the suspension of broken nest material and seawater was washed through a 1-mm sieve and picked through once more with forceps to remove organisms for identification.

The composition of the sessile assemblage varied with depth, with more algae being found in shallow water due to the greater availability of light. The sessile organisms provided food, shelter and an elevated vantage point for motile organisms that were found clustered on the surface of the nests. The vagile epifauna was visibly dominated by brittlestars, although close inspection revealed an abundance of smaller species, such as amphipods and nudibranchs (Appendix A). Together with the organisms found on the nests, there was also an assemblage of animals that co-occupied the complex system of galleries that ramified through each nest. Step (loc. cit.) also noted that L. hians nests frequently accommodate 'guests' that, he said, may act as scavengers. Robertson (in Jeffreys, 1863) mentioned that the porcelain crab (Pisidia longicornis), a scaleworm (Polynoe sp.) and an unidentified greenish gelatinous annelid were all common inhabitants of L. hians nests, while Newbigin (1931) reported the polychaete Flabelligera sp. (as Siphonostoma) living in L. hians nests 'as a commensal'.

In situ observations of the nest-building behaviour of $L$. hians beds in Loch Fyne showed that the walls of the internal galleries of the nests were smoothed with muddy material using the foot. Associated with the walls of the internal galleries was a variety of macrofauna-some may derive nutrition from the faeces of the L. hians (e.g. the polychaete Flabelligera affinis and the bivalve Mysella bidentata), while others will be predators of other inhabitants of the nest system (e.g. the polychaetes Lepidonotus squamatus and Glycera lapidum). The high biodiversity of the Limaria nest association was superimposed on that of the underlying sediment. The expectation might be that sediment underlying a continuous mat of file shell nests would become smothered and anoxic. However, samples taken with an airlift to a depth of $1 \mathrm{~m}$ below the sediment surface (for details, see Hall-Spencer and Atkinson, 1999) showed that the underlying sediment had retained a high infaunal biomass of species, such as the long-lived bivalves Mya truncata, Dosinia exoleta and Tapes rhomboides, together with the holothurian Thyonidium drummondi and the irregular sea urchin Echinocardium pennatifidum. This is presumably because the porous nature of Limaria nests allowed the locally strong currents (to $0.52 \mathrm{~m} \mathrm{~s}^{-1}$ ) to flush through the overlying mantle of Limaria nests. Our list of 284 species (Appendix A) gives only a minimum indication of the diversity associated with Limaria nests. The identification of organisms 
$<1 \mathrm{~mm}$ in size, together with wider scale sampling, including at night and at more times of year, would considerably increase our knowledge of Limaria associates.

\section{DISCUSSION}

Yonge and Thompson (1976) stated that L. hians was 'extremely common in shallow water amongst oarweeds or beds of horse mussels' but this is no longer the general experience. The study of gaping file shells in the Clyde Sea area has a long history (Jeffreys, 1863; Robertson, 1896; Gilchrist, 1898; Yonge, 1936) and records prior to the 1970s show that it was once widespread and common on sublittoral gravel (Allen, 1962; Gilmour, 1967). These bivalves have now disappeared from previous strongholds, such as Skelmorlie Bank, Stravanan Bay (Bute) and the Tan Buoy (Great Cumbrae), where only their dead shells now remain (Hall-Spencer, 1998 and unpublished data). Recent studies indicate that scallop dredging over the past 30 years is a likely cause of a decline in L. hians not only in the Clyde (Hall-Spencer, 1998, 1999; Hall-Spencer and Moore, 2000) but also off the Isle of Man (A. Brand, personal communication) and elsewhere around Britain (Wood, 1988). Another area of concern is raised by the use of tri-butyl tin (TBT) antifouling agents on nets used by salmon farms in Ireland in the 1980s. Minchin et al. (1987) showed that this resulted in the reduction or failure of spat settlement of L. hians, with beds near to a salmon farm reduced to less than $2 \%$ of their former extent. This led to destabilization of the sediment and marked reductions in the abundance of sessile benthos (Minchin et al., 1987). Picton et al. (1994) report on the recovery of these beds following cessation of TBT use but emphasize that their inadvertent near destruction by chemical pollution is another indication of the fragility of this biotope.

As noted above, L. hians shares with pectinid bivalves (scallops) the ability to swim (Yonge, 1936), so non-lethal disturbance could conceivably lead to their re-distribution. Thorson (1957) remarked that this motility would give Limaria the ability to avoid anoxic conditions on the bottom (note also Lenihan and Peterson, 1998 on oysters), or an influx of predators. However, the thin shell of L. hians is delicate so that mechanical impact with, for example, mooring chains, hydraulic dredges or towed demersal fishing gear will likely lead to high levels of mortality. The functional properties of benthic ecosystems (physical, chemical and biological) where Limaria beds are stripped away by such activities will differ considerably from the pristine condition. Given the continuing quest for rapid assessment methods (both physical and biological) of fishing disturbance (Hall, 1999), the status of L. hians (presence of nests, proportion of live versus dead shells) could be a useful indicator of past impacts of demersal fishing gear.

In conclusion, the patchy distribution and apparent declines in the numbers of $L$. hians around the British Isles indicates that this species should be allocated a conservation status that is at least equivalent to that accorded to other biogenic reef-forming organisms. In the short term, both voluntary and statutory conservation bodies should raise public awareness of Limaria reefs and seek to influence the management of activities that impinge upon these delicate marine habitats. In the longer term, the best remaining examples of these reefs should be surveyed in detail and afforded protection within the proposed network of European SACs.

\section{ACKNOWLEDGEMENTS}

This contribution forms part of a wider study (REEFS) funded by the EC as a CFP Study Project (98/018) into the ecological effects of toothed-dredge fishing in European waters. The authors thank Leigh Jones for interrogating the MNCR database on their behalf, Christine Howson for useful discussions and staff/students of the University Marine Biology Station Millport for help throughout. The divers (Ken Cameron, Hugh Brown, Jon Chamberlain), crew of RV AORA (Mick Parker, Billy Sloss and Fraser Hamilton) and field assistants (Harry Goudge, Emma Walker and Guillemette Joly) are thanked especially for their help with fieldwork. 


\section{REFERENCES}

Allen JA. 1962. The Fauna of the Clyde Sea Area. Mollusca. Scottish Marine Biological Association: Millport.

Anadon N. 1981. On the reefs of Sabellaria alveolata (L.) (Polychaeta, Sedentaria) from the Ria de Vigo (NW of Spain). Investigación pesquera 45: 105-122.

BIOMAERL Team. 1999. Final Report. BIOMAERL project (Co-ordinator: PG Moore, University Marine Biological Station, Millport, UK), EC Contract No. MAS3-CT95-0020.

Bosence DWJ. 1973. Recent serpulid reefs, Connemara, Eire. Nature 242: 40-41.

Connor DW, Dalkin MJ, Hill TO, Holt RHF, Sanderson WG. 1997. Marine Nature Conservation Review: Marine Biotope Classification for Britain and Ireland, vol. 2, Sublittoral Biotopes. JNCC Report No. 230: Peterborough.

Côté IM. 1995. Effects of predatory crab effluents on byssus production in mussels. Journal of Experimental Marine Biology and Ecology 188: 233-241.

Cranfield HJ, Michael KP, Doonan IJ. 1999. Changes in the distribution of epifaunal reefs and oysters during 130 years of dredging oysters in Foveaux Strait, southern New Zealand. Aquatic Conservation: Marine and Freshwater Ecosystems 9: 461-483.

Erwin DG, Picton BE, Connor DW, Howson CM, Gilleece P, Bogues MJ. 1990. Inshore Marine Life of Northern Ireland. HMSO: Ulster Museum, Belfast.

Gilchrist JDF. 1898. Lima hians and its mode of life. Transactions of the Natural History Society of Glasgow 4: $218-225$.

Gilmour THJ. 1967. The defensive adaptations of Lima hians (Mollusca, Bivalvia). Journal of the Maine Biological Association of the United Kingdom 47: 209-221.

Hall SJ. 1999. The Effects of Fishing on Marine Ecosytems and Communities. Blackwell Science: London.

Hall-Spencer JM. 1998. Conservation issues relating to maerl beds as habitats for molluscs. In Molluscan Conservation: A Strategy for the 21st Century, Journal of Conchology Special Publication No. 2, Kileen IJ, Seddon MB, Holmes AM (eds). Henry Ling, The Dorset Press: Dorchester; 271-286.

Hall-Spencer JM. 1999. Maerl habitats under threat. Marine Conservation 4: 15.

Hall-Spencer JM, Atkinson RJA. 1999. Upogebia deltaura (Crustacea: Thalassinidea) in the Clyde Sea maerl beds, Scotland. Journal of the Marine Biological Association of the United Kingdom 79: 871-880.

Hall-Spencer JM, Moore PG. 2000. Impacts of scallop dredging on maerl grounds. In Effects of Fishing on Non-target Species and Habitats: Biological, Conservation and Socio-economic Issues, Kaiser MJ, deGroot SJ (eds). Blackwell Scientific: Oxford.

Hayward PJ, Ryland JS. 1996. Handbook of the Marine Fauna of North-West Europe. Oxford University Press: Oxford.

Høistæter T. 1986. An annotated check-list of marine molluscs of the Norwegian coast and adjacent waters. Sarsia 71: $73-145$.

Holt TJ, Rees EI, Hawkins SJ, Seed R. 1998. Biogenic Reefs (Volume IX). An Overview of Dynamic and Sensitivity Characteristics for Conservation Management of Marine SACs. Scottish Association for Marine Science (UK Marine SACs Project).

Howson CM, Picton BE (eds). 1997. The Species Directory of the Marine Fauna and Flora of the British Isles and Surrounding Seas. Ulster Museum and the Marine Conservation Society: Belfast and Ross-on-Wye.

Howson CM, Connor DW, Holt RHF. 1994. The Scottish sea lochs - an account of surveys undertaken for the Marine Nature Conservation Review. Joint Nature Conservation Committee Report No. 164.

Jeffreys JG. 1863. British Conchology, vol. 3. Van Voorst: London; 1-393.

Lenihan HS, Peterson CH. 1998. How habitat degradation through fishery disturbance enhances impacts of hypoxia on oyster reefs. Ecological Applications 8: 128-140.

MacDonald DS, Little M, Eno NC, Hiscock K. 1996. Disturbance of benthic species by fishing activities: a sensitivity index. Aquatic Conservation: Marine and Freshwater Ecosystems 6: 257-268.

MacGinitie GE, MacGinitie N. 1968. Natural History of Marine Animals. McGraw-Hill: New York.

Magorrian BH, Service M. 1998. Analysis of underwater visual data to identify the impact of physical disturbance on horse mussel (Modiolus modiolus) beds. Marine Pollution Bulletin 36: 354-359.

Magorrian BH, Service M, Clarke W. 1995. An acoustic bottom classification survey of Strangford Lough, Northern Ireland. Journal of the Marine Biological Association of the United Kingdom 75: 987-992.

Marine Biological Association. 1957. Plymouth Marine Fauna. Marine Biological Association of the United Kingdom: Plymouth.

Merrill AS, Turner RD. 1963. Nest building in the bivalve mollusc genera Musculus and Lima. The Veliger 6: 55-59.

Minchin D. 1987. Serpula vermicularis L. (Polychaeta: Serpulidae) reef communities from the west coast of Ireland. Irish Naturalists Journal 22: 314-316.

Minchin D, Duggan CB, King W. 1987. Possible effects of organotins on scallop recruitment. Marine Pollution Bulletin 18: 604-608. 
Möbius K. 1883. The Oyster. Report of the Commissioner, Part VIII, Appendix H. US Commission of Fish and Fisheries, Spencer F Baird, Commissioner. Government Printing Office: Washington, DC.

Moore CG, Saunders GR, Harries DB. 1998. The status and ecology of reefs of Serpula vermicularis L. (Polychaeta: Serpulidae) in Scotland. Aquatic Conservation: Marine and Freshwater Ecosystems 8: 645-656.

Newbigin M. 1931. Life by the Seashore: An Introduction to Natural History. George Allen \& Unwin: London (revised by R. Elmhirst).

Newell RIE. 1988. Ecological changes in Chesapeake Bay: are they the result of overharvesting the American oyster, Crassostrea virginica? In Understanding the Estuary: Advances in Chesapeake Bay Research. Proceedings of a Conference, 29-31 March 1988, Baltimore, MD. Chesapeake Research Consortium Publication No. 129, CBP/TRS 24/88; 536-546.

Picton BE, Emblow CS, Morrow CC, Sides EM, Costello MJ. 1994. Marine communities of the Mulroy Bay and Lough Swilly area, north-west Ireland, with an assessment of their nature conservation importance. Internal Report of the BioMar Project.

Praeger RL. 1894. Fauna of Mulroy Bay, Donegal. Irish Naturalist 3: 113-114.

Ray GC, Hayden BP, McCormick-Ray MG, Smith TM. 1997. Land-seascape diversity of the USA east coast coastal zone with particular reference to estuaries. In Marine Biodiversity: Patterns and Process, Ormond RFG, Gage JD, Angel MV (eds). Cambridge University Press: Cambridge; 337-371.

Reimer O, Tedengren M. 1997. Predator-induced changes in byssal attachment, aggregation and migration in the blue mussel, Mytilus edulis. Marine and Freshwater Behaviour and Physiology 30: 251-266.

Robertson D. 1896. On Lima hians. Transactions of the Natural History Society of Glasgow 4: $331-332$.

Seaward DR (ed). 1982. Sea Area Atlas of the Marine Molluscs of Britain and Ireland. Conchological Society/Nature Conservancy Council: Shrewsbury.

Seed R. 1996. Patterns of biodiversity in the macro-invertebrate fauna associated with mussel patches on rocky shores. Journal of the Marine Biological Association of the United Kingdom 76: 203-210.

Service M, Magorrian BH. 1997. The extent of temporal variation of disturbance to epibenthic communities in Strangford Lough, Northern Ireland. Journal of the Marine Biological Association of the United Kingdom 77: $1151-1164$.

Step E. 1927. Shell Life. Frederick Warne: London.

Tebble N. 1966. British Bivalve Seashells: A Handbook for Identification. British Museum (Natural History): London.

Thorson G. 1957. Bottom communities (sublittoral or shallow shelf). In Treatise on Marine Ecology and Paleoecology, vol. 1, Ecology. Memoirs of the Geological Society of America, 67, Hedgpeth JW (ed.); 461-534.

Williams LB, Williams EH. 1990. Global assault on coral reefs. Natural History 4: 47-54.

Wood E (ed). 1988. Sea life of Britain and Ireland. Immel Publishing: London.

Yonge CM. 1936. The evolution of the swimming habit in the Lamellibranchia. Mémoires du Musée Royal D’Histoire Naturelles de Belgique 3: 80-100.

Yonge CM, Thompson TE. 1976. Living Marine Molluscs. Collins: London.

\section{APPENDIX A}

Macroflora (19 species) and invertebrate macrofauna (265 species) recorded on and in six L. hians nests at 10-15 m depth at Creag Gobhainn, Loch Fyne during 1998-1999 (nomenclature follows that of Howson and Picton (1997))

\begin{tabular}{lcc}
\hline Attached to nests & Mainly vagile on nests & Mainly found in nests \\
\hline Macroalgae & Protozoa & Cnidaria \\
Conchocelis phase & Elphidium crispum & Edwardsia claparedii \\
Audouinella sp. & Platyhelminthes & Sipunculida \\
Hildenbrandia sp. & Platyhelminth indet. & Golfingia elongata \\
Corallina officinalis & Nemertea & Golfingia vulgaris \\
Lithothamnion glaciale & Tubulanus annulatus & Phascolion strombus \\
Lithothamnion sonderi & Lineus longissimus & Polychaeta
\end{tabular}


Appendix A (continued)

\begin{tabular}{|c|c|c|}
\hline Attached to nests & Mainly vagile on nests & Mainly found in nests \\
\hline Melobesia membranacea & Polychaeta & Pisione remota \\
\hline Phymatolithon calcareum & Aphrodite aculeata & Alentia gelatinosa \\
\hline Phymatolithon laevigatum & Chelicerata & Harmothoe spinifera \\
\hline Cruoria pelita & Achelia echinata & Lepidonotus squamatus \\
\hline Phyllophora crispa & Endeis spinosa & Pholoe inornata \\
\hline Plocamium cartilagineum & Crustacea & Eteone longa \\
\hline Cryptopleura ramosa & Praunus inermis & Mysta picta \\
\hline Delesseria sanguinea & Apherusa bispinosa & Eulalia viridis \\
\hline Phycodrys rubens & Apherusa jurinei & Eumida sanguinea \\
\hline Pseudolithoderma extensum & Gitana sarsi & Pirakia punctifera \\
\hline Desmarestia aculeata & Stenothoe marina & Glycera lapidum \\
\hline Laminaria saccharina & Acidostoma obesum & Glycera rouxii \\
\hline Ostreobium quikettii & Lysianassa ceratina & Sphaerodorum gracilis \\
\hline Protozoa & Lysianassa plumosa & Hesiospina similis \\
\hline Lagotia viridis & Orchomene nanus & Kefersteinia cirrata \\
\hline Sponges & Scopelocheirus hopei & Nereimyra punctata \\
\hline Leucosolenia sp. & Tryphosella horingi & Trypanosyllis coeliaca \\
\hline Esperiopsis fucorum & Austrosyrrhoe fimbriatus & Typosyllis sp. \\
\hline Cnidaria & Iphimedia nexa & Brania sp. \\
\hline Tubularia indivisa & Iphimedia obesa & Sphaerosyllis bulbosa \\
\hline Tubularia larynx & Liljeborgia pallida & Sphaerosyllis taylori \\
\hline Eudendrium ramosum & Dexamine thea & Autolytus prolifera \\
\hline Lafoea dumosa & Ampelisca spinipes & Nephtys homberii \\
\hline Halecium halecinum & Gammaropsis maculata & Eunice harasii \\
\hline Abietinaria abietina & Gammaropsis nitida & Nematonereis unicornis \\
\hline Sertularella gayi & Ericthonius punctatus & Lumbrineris fragilis \\
\hline Sertularella polyzonias & Microdeutopus versiculatus & Drilonereis filum \\
\hline Sertularia argentea & Munna sp. & Aonides oxycephala \\
\hline Thuiaria articulata & Hippolyte varians & Caulleriella zetlandica \\
\hline Halopteris catharina & Pandalina brevirostris & Chaetozone setosa \\
\hline Kirchenpaueria pinnata & Pandalus montagui & Cirratulus cirratus \\
\hline Nemertesia antennina & Anapagurus hyndmanni & Cirriformia tentaculata \\
\hline Rhizocaulus verticillatus & Pagurus bernhardus & Dodecaceria concharum \\
\hline Clytia hemisphaerica & Pagurus cuanensis & Flabelligera affinis \\
\hline Obelia dichotoma & Pagurus prideux & Pherusa plumosa \\
\hline Obelia geniculata & Galathea intermedia & Mediomastus fragilis \\
\hline Alcyonium digitatum & Hyas araneus & Notomastus latericeus \\
\hline Urticina felina & Hyas coarctatus & Arenicolides ecaudata \\
\hline Metridium senile & Inachus dorsettensis & Scalibregma inflatum \\
\hline Sagartia elegans & Macropodia rostrata & Owenia fusiformis \\
\hline Actinothoe sphyrodeta & Cancer pagurus & Terebellides stroemi \\
\hline Ectoprocta & Liocarcinus corrugatus & Trichobranchus glacialis \\
\hline Pedicellina cernua & Liocarcinus depurator & Amphitrite cirrata \\
\hline Barentsia sp. & Necora puber & Amphitritides gracilis \\
\hline Polychaeta & Carcinus maenas & Eupolymnia nebulosa \\
\hline Platynereis dumerilii & Mollusca & Crustacea \\
\hline Hydroides norvegica & Leptochiton asellus & Monoculodes carinatus \\
\hline Pomatoceros triqueter & Tonicella marmorea & Westwoodilla caecula \\
\hline Protula tubularia & Tonicella rubra & Urothoe elegans \\
\hline Paradexiospira vitrea & Tricolia pullus & Harpinia crenulata \\
\hline Spirorbis spirorbis & Gibbula magus & Parametaphoxus fultoni \\
\hline Crustacea & Gibbula tumida & Guernea coalita \\
\hline Verruca stroemia & Gibbula cineraria & Ceradocus semiserratus \\
\hline
\end{tabular}


Appendix A (continued)

\begin{tabular}{|c|c|c|}
\hline Attached to nests & Mainly vagile on nests & Mainly found in nests \\
\hline Balanus balanus & Gibbula umbilicalis & Maera othonis \\
\hline Balanus crenatus & Jujubinus miliaris & Conilera cylindracea \\
\hline Ampelisca spinipes & Calliostoma zizyphinum & Eurydice pulchra \\
\hline Gammaropsis maculata & Tectura virginea & Cymodoce truncata \\
\hline Gammaropsis nitida & Lacuna vincta & Leptognathia breviremis \\
\hline Ericthonius punctatus & Trivia monacha & Tanaopsis graciloides \\
\hline Microdeutopus versiculatus & Polinices montagui & Pisidia longicornis \\
\hline Jassa marmorata & Polinices pulchellus & Mollusca \\
\hline Corophium bonnellii & Buccinum undatum & Emarginula fissura \\
\hline Mollusca & Colus gracilis & Skenea serpuloides \\
\hline Mytilus edulis & Neptunea antiqua & Skeneopsis planorbis \\
\hline Modiolus modiolus & Hinia incrassata & Rissoa interrupta \\
\hline Pecten maximus & Elysia viridis & Rissoa rufilabrum \\
\hline Aequipecten opercularis & Aplysia punctata & Rissoa parva \\
\hline Chlamys varia & Pleurobranchus membranaceus & Alvania beani \\
\hline Heteranomia squamula & Tritonia plebia & Alvania punctura \\
\hline Pododesmus patelliformis & Lomanotus marmoratus & Onoba aculeus \\
\hline Bryozoa & Doto coronata & Onoba semicostata \\
\hline Crisia $\mathrm{sp}$. & Doto fragilis & Pusillina inconspicua \\
\hline Tubulipora sp. & Onchidoris bilamellata & Marshallora adversa \\
\hline Lichenopora sp. & Onchidoris muricata & Vitreolina philippi \\
\hline Disporella hispida & Polycera quadrilineata & Chrysallida decussata \\
\hline Alcyonidium diaphanum & Limacia clavigera & Chrysallida indistincta \\
\hline Bugula sp. & Archidoris pseudoargus & Chrysallida intersincta \\
\hline Scrupocellaria sp. & Coryphella lineata & Ondina divisa \\
\hline Cellaria sp. & Coryphella verrucosa & Partulida pellucida \\
\hline Parasmittina sp. & Flabellina pedata & Cylichna cylindracea \\
\hline Phoronida & Catriona gymnota & Diaphana minuta \\
\hline Phoronis (two spp.) & Cuthona caerulea & Nucula nucleus \\
\hline Tunicata & Eubranchus sp. A & Limaria hians \\
\hline Clavelina lepadiformis & Eubranchus tricolor & Mysella bidentata \\
\hline Diplosoma listerianum & Facelina auriculata & Goodalia triangularis \\
\hline Ciona intestinalis & Facelina bostoniensis & Hiatella arctica \\
\hline Corella parallelogramma & Aeolidia papillosa & Thracia villosiuscula \\
\hline Ascidiella aspersa & Echinodermata & Echinodermata \\
\hline Ascidiella scabra & Antedon bifida & Ophiopholis aculeata \\
\hline Ascidia mentula & Luidia ciliaris & Echinocyamus pusillus \\
\hline Ascidia virginea & Porania pulvillus & Thyone fusus \\
\hline Dendrodoa grossularia & Solaster endeca & Labidoplax media \\
\hline \multirow[t]{9}{*}{ Botryllus sclosseri } & Crossaster papposus & \\
\hline & Henricia sp. & \\
\hline & Asterias rubens & \\
\hline & Marthasterias glacialis & \\
\hline & Ophiothrix fragilis & \\
\hline & Ophiocomina nigra & \\
\hline & Psammechinus miliaris & \\
\hline & Echinus esculentus & \\
\hline & Ocnus planci & \\
\hline
\end{tabular}

